\title{
Efektivitas Penerapan Blended Learning dengan Moodle sebagai Media Pembelajaran untuk Mata Pelajaran Simulasi Digital
}

\author{
Irma Yuliana \\ Pendidikan Teknik Informatika \\ Fakultas Keguruan dan Ilmu Pendidikan \\ Universitas Muhammadiyah Surakarta \\ Surakarta \\ Irma.yuliana@ums.ac.id
}

\author{
Leni Zuliana Fitri \\ Fakultas Keguruan dan Ilmu \\ PendidikanPendidikan Teknik Informatika \\ Universitas Muhammadiyah Surakarta \\ Surakarta \\ leni.zuliana@gmail.com
}

\begin{abstract}
Abstrak--Penelitian ini bertujuan untuk mengetahui pengembangan, kelayakan dan keefektifan Moodle sebagai media pembelajaran terintegrasi dengan sistem konvensional untuk mata pelajaran Simulasi Digital kelas $X$ di lingkungan SMK Muhammadiyah Kartasura Sukoharjo. Metode penelitian yang digunakan adalah metode Research and Development (R\&D) dengan menggunakan model pengembangan waterfall. Pengembangan Moodle sebagai media pembelajaran untuk mata pelajaran Simulasi Digital melalui tahap abalysis, design, implementation, testing, dan maintenance. Pengumpulan data dilakukan melalui tes dan non tes. Teknik analisis yang digunakan adalah kelayakan.. Hasil penilaian ahli media dikatakan sangat layak dengan rata-rata keseluruhan mendekati $100 \%$ dan penilaian dari ahli materi termasuk kategori sangat layak dengan rata-rata keseluruhan $\mathbf{9 5 , 4 \%}$. Berdasarkan hasil uji Mann-Whitney $U$ Test diperoleh sig (2-tailed) sebesar 0,00, jika sig $<0,05$ maka $\mathrm{HO}$ tidak diterima dan Ha diterima yang artinya ada perbedaan hasil belajar dari peserta didik sebelum dan sesudah menggunakan media. Berdasarkan hasil penelitian Moodle sebagai media blended learning pada mata pelajaran simulasi digital dinyatakan layak digunakan untuk meningkatkan pemahaman dan hasil belajar peserta didik.
\end{abstract}

Kata kunci: blended learning, Moodle, Simulasi Digital

\section{PENDAHULUAN}

Metode pengajaran tradisional memiliki keunggulan dalam mentransmisikan sejumlah besar pengetahuan kepada siswa dengan sistematis logika dan dengan kontak emosional yang kuat antara guru dan siswa. Sedangkan sistem pembelajaran dalam jaringan (daring) sangat berharga dalam memberikan fleksibilitas pengalaman belajar dan memenuhi beragam kebutuhan siswa. Blended learning adalah pedagogi yang menggabungkan fitur instruksi tradisional dan kelebihan $e$ learning [1]. Pembelajaran daring yang digunakan dalam penelitian ini menggunakan platform Moodle [2] yang membangun sistem manajemen pendidikan tidak hanya alat untuk kursus tetapi juga platform untuk pengembangan kegiatan pendidikan itu sendiri secara utuh [3].

Teknologi informasi dan komunikasi dapat membantu mempermudah proses belajar mengajar menjadi lebih baik. Perkembangan teknologi informasi juga telah memunculkan sistem teknologi informasi komunikasi nirkabel yang terpadu dengan perangkat pengolahan informasi berbasis jaringan global (internet) sehingga dimensi ruang dan waktu kini tidak lagi membatasi dua pihak atau lebih untuk saling berinteraksi.

Nasional Berbasis Komputer) kelas XII. Hal yang cukup penting, pembelajaran dengan metode blended sangat berguna
Internet dengan dukungan web2.0 telah dirancang untuk menumbuhkan kreativitas, komunikasi, pertukaran informasi keamanan, kolaborasi dan berbagi sumber daya, sehingga perlu diintegrasikan dalam kegiatan belajar mengajar [4] sebagai model pembelajaran hybrid.

Simulasi digital merupakan salah mata pelajaran baru semua kompetensi keahlian pada kurikulum 2013, juga dalam Kompetensi Keahlian Teknik Komputer dan Jaringan (TKJ). Materi pembelajaran Simulasi Digital dalam penelitian ini adalah tentang Peta Minda di kelas X semester 1. Standar kompetensi dan kompetensi dasar sesuai dengan silabus dan materi yang diajukan menjadi bahan penelitian berdasarkan panduan Kurikulum 2013 Revisi. Peta Minda dapat dibuat dengan atau tanpa perangkat lunak. Jika memanfaatkan perangkat lunak, beberapa perangkat lunak yang dapat diinstal pada komputer dan berlisensi open source, yaitu FreeMind atau XMind.

Moodle singkatan dari Modular Object Oriented Dynamic Learning Environment. Keberadaan Moodle memungkinkan kita membangun sistem pembelajaran dengan konsep E- Learning (pembelajaran secara elektronik) ataupun Distance Learning (Pembelajaran Jarak Jauh)[2]. Sistem pembelajaran dengan platform ini tidak terbatas ruang dan waktu. Pengajar dapat memberikan materi pembelajaran dimana saja. Seorang pembelajar juga dapat mengikuti dari mana saja tanpa harus hadir dalam suatu tempat. Interaksi yang terjalin dalam proses pembelajaran dibagi menjadi 3 tingkatan yang berbeda yaitu konseptualisasi (interaksi dengan konsep), konstruksi (interaksi dengan tugas) dan dialog (interaksi dengan orang/pengajar/pembelajar lainnya/administrator). Moodle dapat diakses di www.moodle.org.

Berangkat dari latar belakang, berdasarkan hasil wawancara dan observasi awal di SMK Muhammadiyah Kartasura bahwasannya proses pembelajaran yang selama ini dilakukan pada mata pelajaran simulasi digital sejak di terapkan kurikulum 2013 belum bisa dilakukan secara maksimal karena ada beberapa faktor, pembelajaran masih bersifat konvensional dan teacher oriented. Pembelajaran selama ini hanya bersumber pada guru. Sedangkan dalam mata pelajaran Simulasi Digital dibutuhkan metode dan sumber belajar lain yang bisa mendukung proses pembelajaran. Metode blended/hybrid learning mulai dikenalkan di seluruh pelosok negeri, dalam UNBK (Ujian ketika peserta didik menjalankan prakerin (Praktek Kerja Industri) diluar sekolah selama kurang lebih 2 bulan. Dalam 
jangka waktu itu peserta didik tidak melaksanakan KBM di sekolah, namun akan tetap dapat mengikuti materi yang diajarkan.

Pengembangkan dan pemanfaatan e-learning menggunakan moodle untuk pembelajaran memberikan kesempatan kepada siswa untuk berpikir terbuka dengan mengerjakan soal-soal latihan secara kreatif diantaranya yaitu keaslian dalam bekerja, keluwesan [5] Siswa dapat melakukan aktivitas dan berkomunikasi dalam perkuliahan tanpa harus tatap muka, tetapi cukup melihat di website e-learning ada tugas atau tidak dan dapat segera mengirimkan tugasnya serta dapat mencari sumber belajar lainnya sebagai bahan rujukan.

Sebuah penelitian [6] menunjukkan bahwa pelaksanaan pembelajaran e-learning di sebuah sekolah yaitu SMK Telkom Sandhy Putra Purwokerto sesuai dengan standar mutu pelaksanaan e-learning dinilai cukup efektif pada komponen perencanaan pembelajaran, perancangan dan pembuatan materi, penyampaian pembelajaran, komponen interaksi pembelajaran dan komponen evaluasi pelaksanaan pembelajaran e-learning dinilai cukup efektif dengan masing masing kecenderungan secara berurutan sebagai berikut: $77,57 \%, \quad 75,14 \%, \quad 75 \%, \quad 66,10 \%$ dan $69,01 \%$. Secara keseluruhan dapat disimpulkan bahwa pelaksanaan pembelajaran e-learning sebagai media pembelajaran di SMK Telkom Sandhy Putra Purwokerto cukup efektif dengan tingkat kecenderungan 77,27\%.

Berdasarkan urian diatas, peneliti bermaksud untuk mendapatkan suatu produk berupa media pembelajaran Moodle melalui sebuah penelitian yang bertujuan untuk mengetahui pegembangan, kelayakan dan keefektifan Moodle sebagai media pembelajaran untuk mata pelajaran simulasi digital kelas X SMK Muhammadiyah Kartasura.

\section{METODE PENELITIAN}

Penelitian melalui pengembangan ini memiliki tujuan membangun sebuah media pembelajaran Moodle (e-learning) Simulasi Digital. Berdasarkan tujuan tersebut, digunakan metode Research and Development (R\&D) dengan metode SDLC (System Development Life Cycle) waterfall yang mencakup beberapa tahapan yaitu :(1), Analisis Data Produk, (2) Tahap Desain, (3) dan Implementasi (4) Testing seperti pada gambar 1 .

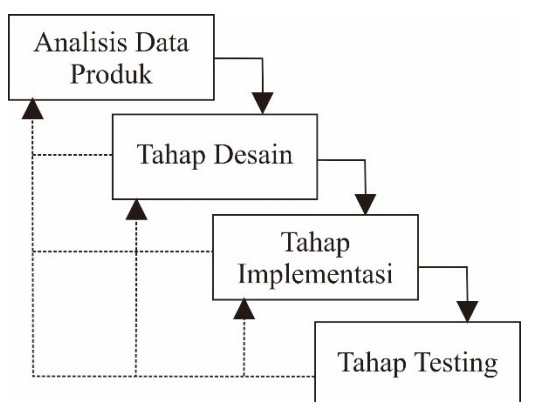

Gambar 1. Bagan Proses Pengembangan

Analisis produk dilakukan langsung di lingkungan sekolah , sehingga melalui pengamatan dan wawancara, sehingga dirumuskan agar perlu adanya sistem pembelajaran yang terintegrasi agar siswa tetap dapat menerima materi saaat paraktek kerja lapangan. Pada tahap desain dilakukan pendekatan dengan Unified Modeling Languange (UML) melalui use case diagram dan activity diagram.

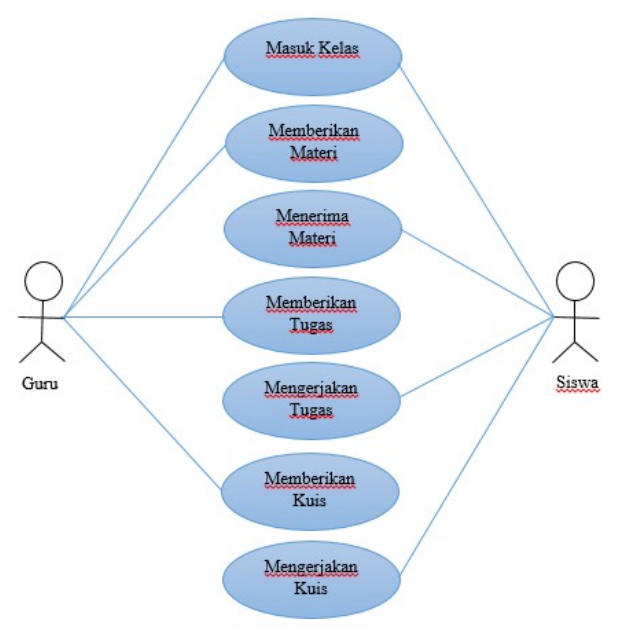

Gambar 2. Use Case Diagram

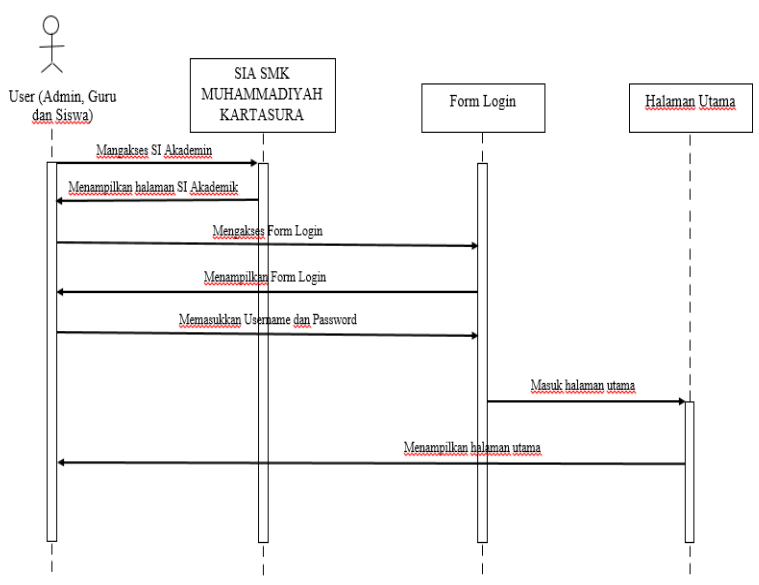

Gambar 3. Activity Diagram

Populasi dalam penelitian ini yaitu dosen dan guru sebagai ahli media dan ahli materi dalam uji validasi serta peserta didik kelas X SMK Muhammadiyah Kartasura sebagai responden saat uji dilapangan. Sampel saat uji dilapangan adalah 1 dosen dari Program Studi Teknik nformatika sebagai ahli media dan 1 guru kelas $\mathrm{X}$ dari SMK Muhammadiyah kartasura sebagai ahli materi. Untuk sampel responden dilakukan pada kelas X MA (Mesin) SMK Muhammadiyah Kartasura, Sukoharjo.

Teknik pengumpulan data awal pada penelitian menggunakan wawancara dan obesrvasi kepada guru dan peserta didik untuk menganalisis permaslahan yang ada disekolah. Kemudian untuk pengumpulan data untuk mengetahui kelayakan dilakukan uji validasi dan uji dilapangan dengan menyebar angket sedangkan untuk mengetahui keefektifan dari media dilakukan pre-test dan post-test serta dokumentasi untuk memperkuat bukti penelitian. Data angket dari responden diukur atau dihitung menggunakan skala likert yakni jawaban dari pernyataan angket diberi skor ketetapan. Data skor hasil dihitung menggunakan rumus statistic presentase dengan rumus sebagai berikut.

$$
P=\frac{f}{N} \times 100 \%
$$


Keterangan :

$\mathrm{P} \quad=$ angka persentase

$\mathrm{f} \quad=$ frekuensi yang sedang dicari peresentasenya

$\mathrm{N} \quad=$ number of cases (jumlah frekuensi/banyakanya individu)

Hasil hitung persentase yang diperoleh dari data angket, selanjutnya presentasikan dengan ukuran kriteria penilaian. Adapun ukuran kriteria penilaian diperoleh dengan cara menentukan panjang interval, maka diperoleh ukurankriteria penilaian sebagai pada tabel 1 berikut :

Tabel 1. Rentang Kriteria Penilaian

\begin{tabular}{|c|c|}
\hline Persentase & Kriteria \\
\hline $81,25 \%-100 \%$ & Sangat Layak \\
\hline $62,50 \%-81,24 \%$ & Layak \\
\hline $43,75 \%-62,49 \%$ & Cukup \\
\hline $25 \%-43,74 \%$ & Tidak Layak \\
\hline
\end{tabular}

Kemudian untuk data hasil belajar dari peserta didik dilakukan beberapa ujian untuk mengetahui keefektifan dari media yang dikembangkan, berikut ini uji yang dilakukan:

a. Uji Normalitas

Uji normalitas ini untuk mengetahui apakah data telah berdistribusi normal atau tidak. Sudjana (2005:273) untuk melakukan uji normalitas digunakan Chi kuadrat dengan rumus :

$$
X^{2}=\sum_{i=1}^{k} \frac{(O i-E i)^{2}}{E i}
$$

Keterangan :

$\mathrm{X}^{2}=$ Chi Kuadrat

Oi $=$ Frekuensi pengamatan

Ei $=$ Fekuensi yang diharapkan

b. Uji N-gain

Uji $\mathrm{N}$-gain ini digunakan untuk mengetahui gain ternormalisasi atau belum, menghitung $\mathrm{N}$-gain dapat menggunakan rumus sebagai berikut :

$$
N-\text { gain }=\frac{\text { Skor posttes }- \text { Skor } \text { pretest }}{\text { SMI }- \text { Skor posttes }}
$$

Keterangan :

SMI $=$ Skor Maksimal Ideal

Hasil dari uji N-gain kemudian diklasifikasikan sesuai dengan kriteria yang ditetapkan dapat dilihat pada Tabel 2:

Tabel 2. Kriteria N-gain

\begin{tabular}{|c|c|}
\hline Interval Koefisien & Kriteria \\
\hline $\mathrm{N}$-gain $<0,3$ & Rendah \\
\hline $0,3<\mathrm{N}$-gain $<0,7$ & Sedang \\
\hline $\mathrm{N}$-gain $>0,7$ & Tinggi \\
\hline
\end{tabular}

c. Uji Mann-Whitney U Test

Adapun rumus dari Mann-Whitney $U$ test menurut Sulaiman (2003) adalah sebagai berikut:

$\mathrm{U} 1=\mathrm{n} 1 \times \mathrm{n} 2+1 / 2\{\mathrm{n} 1(\mathrm{n} 1+1)\}-\mathrm{R} 1$

dan

$\mathrm{U} 1=\mathrm{n} 1 \times \mathrm{n} 2+1 / 2\{\mathrm{n} 1(\mathrm{n} 1+1)\}-\mathrm{R} 1$
Keterangan :

$\mathrm{n} 1=$ jumlah sampel 1

$\mathrm{n} 2=$ jumlah sampel 2

$\mathrm{U} 1=$ jumlah peringkat 1

$\mathrm{U} 2=$ jumlah peringkat 2

$\mathrm{R} 1=$ jumlah rank sampel $\mathrm{n} 1$

$\mathrm{R} 2=$ jumlah rank sampel n2

\section{HASIL PENELITIAN DAN PEMBAHASAN}

A. Hasil

Pada tampilan awal Moodle, terdapat course Simulasi Digital kelas $\mathrm{X}$ dengan guru yang mengajar, selain itu terdapat langkah-langkah atau petunjuk untuk $\log$ in ke Moodle.

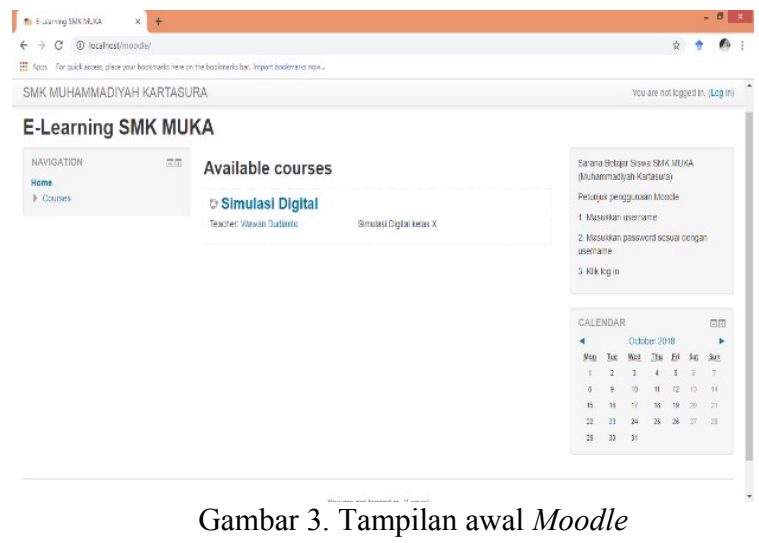

Tampilan Log in Moodle, pada tampilan ini setiap user harus memasukkan username dan password terlebih dahulu sebelum masuk ke media Moodle.

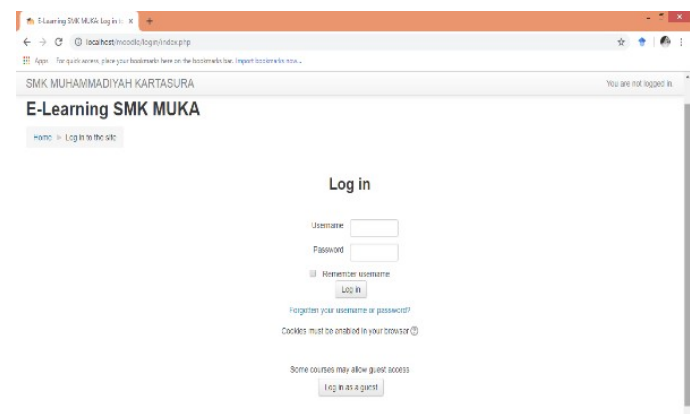

Gambar 4. Tampilan Log in Moodle

Tampilan Home siswa, pada tampilan ini terdapat menu navigation yang dimana pada menu navigation ini terdapat tombol home, pages dan courses. Untuk tombol courses didalamnya terdapat tingkatan kelas dan pilihan mata pelajaran, selain itu juga terdapatan nama guru yang mengajar di kelas tersebut. 


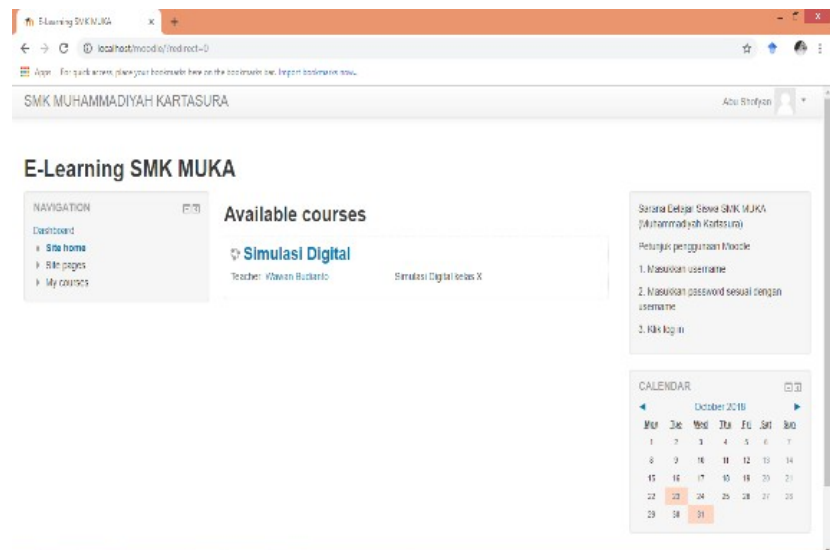

Gambar 5. Tampilan Home Siswa

Tampilan Kuis siswa, pada tampilan ini menampilkan soal kuis yang diberikan oleh guru, setelah klik tombol Attempt quiz now maka akan muncul soal-soal pilihan ganda yang akan dikerjakan dalam waktu pengerjaan sesuai dengan waktu yang diberikan.

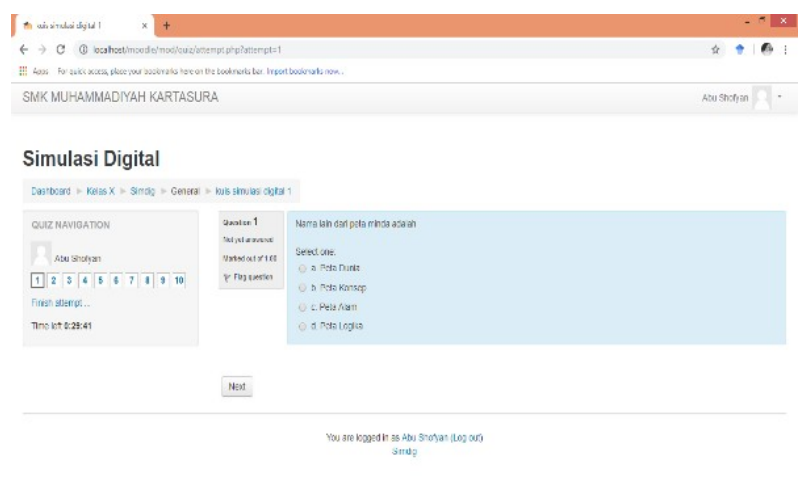

Gambar 6. Tampilan Kuis Siswa

Tampilan Submit Kuis, pada tampilan ini setelah peserta didik selesai mengerjakan kuis maka langkah selanjutnya yaitu submit kuis.

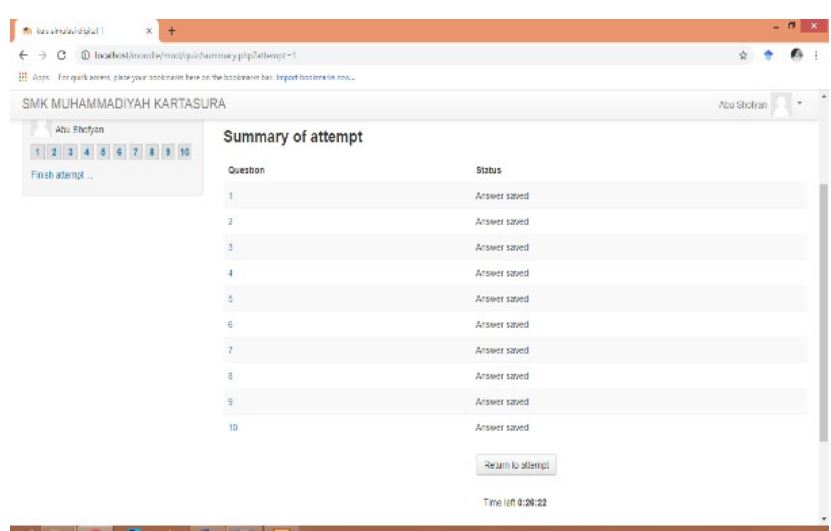

Gambar 7. Tampilan Submit Kuis

Tampilan Akhir Kuis, pada tampilan akhir kuis siswa ini menampilkan hasil akhir dari kuis yang telah dikerjakan oleh peserta didik, pada halaman ini peserta didik akan mengetahui jumlah skor yang didapatkan selama mengerjakan kuis.

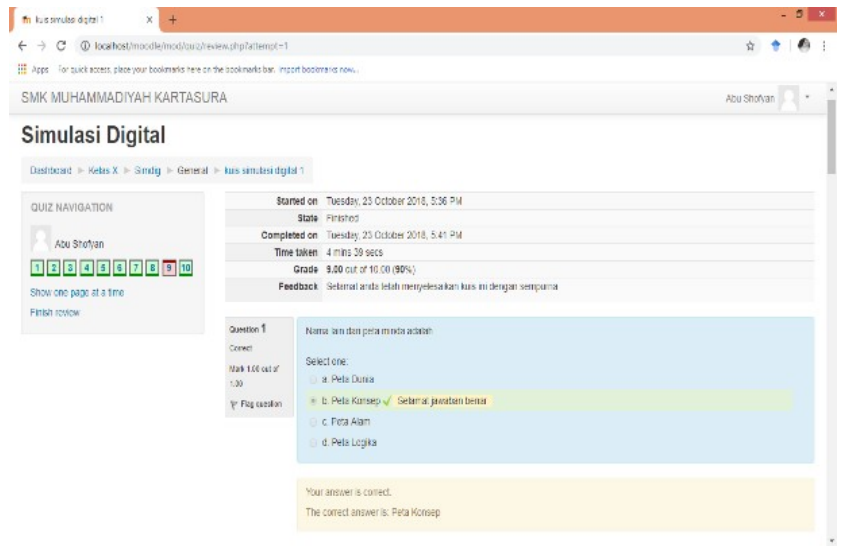

Gambar 8. Tampilan Akhir Kuis

Pada tahap validasi dilakukan, uji coba kepada validator media dengan hasil dari validasi media tersaji pada gambar 9.

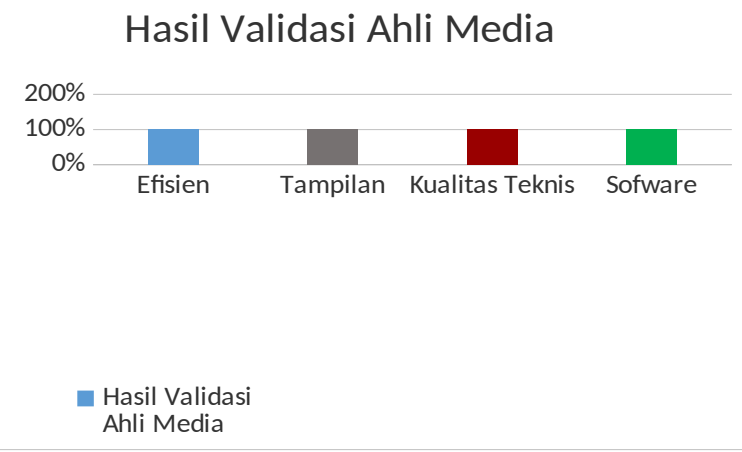

Gambar 9.Grafik Hasil Validasi Media

Berdasarkan hasil validasi ahli media yang dapat dilihat paga gambar bahwasannya untuk hasil penilaian pada aspek efisien mendapatkan penilaian $100 \%$ yang dikategorikan sangat layak, untuk aspek tampilan mendapatkan penilaian sebesar 100\% yang dikategorikan sangat layak, sedangkan untuk aspek kualitas teknik mendapatkan penilaian sebesar $100 \%$ yang dikategorikan sangat layak, dan untuk aspek software mendapatkan penilaian sebesar $100 \%$ yang dikategorikan sangat layak, Maka untuk penilaian dari ahli media kepada semua aspek yang diuji cobakan mendapatkan kategori sangat layak dengan rata-rata sebesar $100 \%$. Berdasarkan dari hasil penilaian tersebut maka dapat disimpulkan bahwa Moodle sebagai media pembelajaran untuk mata pelajaran simulasi digital ini sangat layak digunakan sebagai media pembelajaran didalam kelas.

Sedangkan pada hasil validasi oleh ahli materi, yaitu oleh seorang guru kelas di sekolah ybs, diperoleh hasil seperti yang tersaji pada gambar 10 . 


\section{Hasil Validasi Ahli Materi}

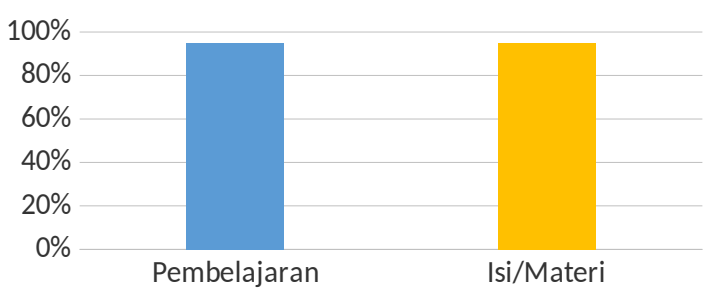

Hasil Validasi Ahli Materi

Gambar 10. Grafik Hasil Validasi Materi

Berdasarkan hasil validasi materi yang dapat dilihat pada gambar bahwasannya untuk penilain pada aspek pembelajaran mendapatkan 95,8\% yang dikategorikan sangat layak, dan untuk aspek isi/materi mendapatkan penilaian sebesar $95 \%$ yang dikategorikan sangat layak. Maka untuk penialaian dari ahli materi kepada semua aspek yang diuji cobakan mendapatkan kategori sangat layak dengan rata-rata sebesar 95,4\%. Berdasarkan dari hasil penilaian tersebut dapat disimpulkan bahwasannya Moodle sebagai media pempelajaran Simulasi Digital dapat digunakan sebagai media pembelajaran.

Hasil angket respon pesrta didik diperoleh melalui uji coba yang dilaksanakan di SMK Muhammadiyah Kartasura pada kelas X MA dengan jumlah peserta didik sebanyak 25 peserta didik. Hasil dari keseluruhan penilaian yang dilakuakan peserta didik tersaji pada gambar 11 .

\section{Hasil Keseluruhan Penilaian Peserta Didik}

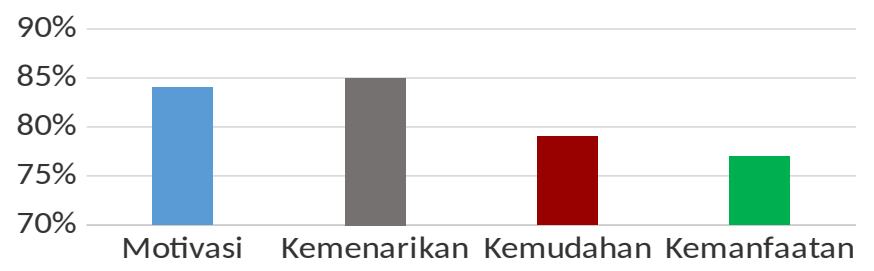

Gambar 11.Grafik Hasil Keseluruhan Penilaian Peserta Didik

Berdasarkan hasil respon/tanggapan dari peserta didik yang dapat dilihat pada gambar bahwasannya untuk hasil penilaian pada aspek motivasi mendapatkan penilaian sebesar $84,2 \%$ yang dikategorikan sangat layak, untuk aspek kemenarikan mendapatkan penilaian sebesar $85,4 \%$ yang dikategorikan sangat layak, sedangkan pada aspek kemudahan mendapatkan penilaian sebesar 79,6 yang dikagorikan layak, untuk aspek kemanfaatan mendapatkan penilaian sebesar $77,5 \%$ yang dikategorikan layak. Maka penilaian secara keseluruhan kepada semua aspek yang telah diuji cobakan mendapatkan rata-rata sebesar $81,62 \%$ yang dikategorikan sangat layak.

\section{B. Pembahasan}

Pada validasi kelayakan media yang dilakukan kepada ahli materi dan ahli media secara keseluruhan $97.7 \%$ yang dikategorikan sangat layak digunakan sebagai media pembelajaran. Media dianggap layak digunakan sebagai media pembelajaran untuk mendukung pembelajaran dikarenakan dari desain tampilan dan fitur-fitur yang digunakan selalu konsisten, dari segi isi/materi telah disajikan secara sistematis dan kesesuaian materi tentang Peta Minda Simulasi Digital, dan untuk segi pembelajarannya telah sesuai dengan KI KD dan indikator yang ada pada silabus maupun RPP yang digunakan oleh guru. Dari hasil tersebut maka media pembelajaran bisa dilanjutkan ke tahap selanjutnya yaitu uji coba lapangan guna untuk diuji keefektifannya.

Pada kegiatan pembelajaran, komunikasi terjalin antara guru dan peserta didik melalui pemanfaatan e-learning. Informasi yang disajikan melalui e-learning dapat dengan mudah diperoleh peserta didik kapan pun sehingga didalam mengerjakan tugas tidak mengalami kendala. Pemanfaatan pesan singkat pada e-learning digunakan peserta didik di dalam berinteraksi dengan guru tentang materi pada mata pelajaran tersebut. Kendala peserta didik di dalam menggunakan e-learning karena masih mahasiswa masih menganggap beluma danya kebutuhan yang mendesak pada saat penerapan e-learning.

\section{SIMPULAN}

Berdasarkan hasil pembahasan penelitian, dapat disimpulkan bahwa Moodle sebagai pelengkap dalam sistem blended learning untuk mata pelajaran simulasi digital layak dan efektif digunakan dalam proses pembelajaran di kelas. Perolehan hasil penelitian dari ahli media sebesar 100\% dengan kategori sangat layak, untuk hasil penilaian dari ahli materi sebesar 95,4\% dengan kategori sangat layak, dan respon dari peserta didik memiliki keseluruhan hasil penilaian sebesar $81,87 \%$ dengan kategori sangat layak. Aplikasi e-learning menggunakan platform Moodle sebagai media pembelajaran untuk mata pelajaran simulasi digital efektif digunakan untuk meningkatkan pemahaman peserta didik, hal ini dibuktikan dari hasil pre-tset dan post-test terdapat peningkatan sebanyak 0,73 yang termasuk dalam kategori tinggi

\section{DAFTAR PUSTAKA}

[1] M. Li, Y. Ni, P. Zhou, and Y. Zheng, "Pedagogy in the information age: Moodle-based blended learning approach," IFCSTA 2009 Proc. - 2009 Int. Forum Comput. Sci. Appl., vol. 3, pp. 38-40, 2009.

[2] T. Lamia, H. Ashouri, and T. Sarra, "Lesson via the elearning platform MOODLE," $2017 \mathrm{Jt}$. Int. Conf. Inf. Commun. Technol. Educ. Train. Int. Conf. Comput. Arab. ICCA-TICET 2017, 2017.

[3] Ž. Namestovski, M. Takács, and B. Arsović, "Supporting traditional educational process with e-learning tools," 2012 IEEE 10th Jubil. Int. Symp. Intell. Syst. Informatics, SISY 2012, pp. 461-464, 2012.

[4] T. Mchichi, P. Estraillier, and K. Afdel, "Web 2.0 based elearning: Moodle-openmeetings platform," Int. Conf. Multimed. Comput. Syst. -Proceedings, 2011.

[5] Hermawanto, S. Kusairi, and Wartono, "Pengaruh Blended Learning Terhadap Penguasaan Konsep dan Penalaran Fisika Peserta Didik Kelas X," J. Pendidik. Fis. 
Efektivitas Penerapan Blended Learning dengan Moodle sebagai Media Pembelajaran untuk Mata Pelajaran Simulasi Digital

Indones., vol. 9, no. 57, pp. 67-76, 2013.

[6] N. S. Hanum, "Keefetifan e-learning sebagai media pembelajaran (studi evaluasi model pembelajaran e-learning SMK Telkom Sandhy Putra Purwokerto)," J. Pendidik. Vokasi, vol. 3, no. 1, pp. 90-102, 2018. 